\title{
Multiple Primary Tumors of the Gastrointestinal Tract: Our Six-year Results
}

\section{Gastrointestinal Sistemin Çoklu Primer Tümörleri: Altı Yıllık Sonuçlarımız}

\section{(D) Selma Şengiz Erhan1, (D) Selvi Tabak Dinçer2, (D) Emre Uysal2, (D) Ali Alemdar3}

1İstanbul Prof. Dr. Cemil Taşcıŏlu City Hospital, Clinic of Pathology, İstanbul, Turkey

2İstanbul Prof. Dr. Cemil Taşcıoğlu City Hospital, Clinic of Radiation Oncology, İstanbul, Turkey

3İstanbul Prof. Dr. Cemil Taşcıoğlu City Hospital, Clinic of General Surgery, İstanbul, Turkey

\section{Abstract}

Objective: Multiple primary tumors (MPTs) are tumors that develop simultaneously or at different times in the same or different organs. They are divided into two groups as synchronous and metachronous tumors. Genetic instability, gene mutation, immunodeficiency, prolongation of life span with chemotherapy, radiotherapy and target treatments are among the reasons that increase the development of the second primary tumor. In our study, we aimed to present cases with MPTs accompanying gastrointestinal system (GIS) tumors with clinicopathological features.

Method: The cases having the criteria of MPT among the cases diagnosed with primary tumor discussed in the GIS councils of our hospital between 2014 and 2019 were included in our study.

Results: A total of 162 cases (4.7\%) with a diagnosis of MPT were detected. While 52 of the cases were in the synchronous tumor group and 110 were in the metachronous tumor group. Most of the patients in both groups were male (59.9\%). The most common MPT groups observed in men were left colon-prostate and rectum-right colon tumors, and stomach-breast and left colon-breast tumors in women. The second primary tumors accompanying GIS tumors in the synchronous and metachronous tumor groups belonged to the GIS and urogenital system. Survival rates were lower in cases with metachronous tumors than in cases with synchronous tumors, but the intergroup difference was not statistically significant. The survival rate in cases of GIS malignancy originating from the stomach was lower compared to cases with other GIS malignancies with a statistically significant difference.

Conclusion: In terms of GIS tumors, prostate and colon tumors in men and breast tumors in women may be risk factors for the development of MPTs.

Keywords: Gastrointestinal system, metachronous, multiple primary tumor, synchronous

\section{Öz}

\begin{abstract}
Amaç: Çoklu primer tümörler (ÇPT) eş zamanlı ya da farklı zamanda aynı ya da farklı organlarda gelişen tümörlerdir. Senkron ve metakron tümör olarak iki gruba ayrılmaktadırlar. Genetik instabilite, gen mutasyonu, immün yetmezlik, kemoterapi, radyoterapi ve hedef tedavileri ile yaşam süresinin uzaması ikinci primer tümör gelişimini artıran nedenler arasında sayılmaktadır. Çalışmamızda gastrointestinal sistem (GiS) tümörleri ile birliktelik gösteren ÇPT'li olguları klinikopatolojik özellikleriyle birlikte sunmayı amaçladık.
\end{abstract}

Yöntem: Çalışmamıza 2014-2019 yılları arasında hastanemiz GiS konseylerinde tartışılan primer tümör tanısı almış olgular içinden ÇPT kriterleri taşıyan olgular dahil edildi.

Bulgular: ÇPT tanılı 162 olgu $(\% 4,7)$ saptandı. Olguların 52'si senkron, 110 'u metakron tümör grubundaydı. Her iki grupta olguların çoğu erkekti $(\% 59,9)$. Erkeklerde en sık izlenen çoklu primer tümör grubu sol kolonprostat ve rektum-sağ kolon iken, kadınlarda mide-meme ve sol kolonmemeydi. Senkron ve metakron tümör grubunda GiS tümörlerine eşlik eden ikinci primer tümörler GiS ve ürogenital sisteme aitti. Sağkalım oranları metakron tümörlü olgularda senkron tümörlü olgulara göre daha düşük saptandı, ancak aradaki fark istatistiksel olarak anlamlı değildi. Gis malignitesi mide kaynaklı olgularda sağkalım oranı, diğer GiS malignitesi olan olgularla karşılaştırıldığında daha düşüktü ve istatistiksel olarak anlamlıydı.

Sonuç: GiS tümörleri açısından erkeklerde prostat ve kolon, kadınlarda ise meme tümörleri ÇPT gelişimi için risk faktörü olabilir.

Anahtar kelimeler: Çoklu primer tümör, gastrointestinal sistem, metakron, senkron

Address for Correspondence: Selma Şengiz Erhan, İstanbul Prof. Dr. Cemil Taşcıoğlu City Hospital, Clinic of Pathology, İstanbul, Turkey E-mail: selmaserhan@hotmail.com ORCID: orcid.org/0000-0001-8810-8806 Received: 17.11.2020 Accepted: 02.02.2021

Cite this article as: Şengiz Erhan S, Dinçer Tabak S, Uysal E, Alemdar A. Multiple Primary Tumors of the Gastrointestinal Tract: Our Six-year Results. Bagcilar Med Bull 2021;6(2):148-156

๑) Copyright 2021 by the Health Sciences University Turkey, Bagcilar Training and Research Hospital Bagcilar Medical Bulletin published by Galenos Publishing House. 


\section{Introduction}

Multiple primary tumors (MPTs) are tumors that develop simultaneously or at different times in the same or different organs. Three features should be present in these tumors; each tumor should be proven to be malignant, histologically different, and should not be the recurrence or metastasis of another tumor (1). MPTs are divided into two groups as synchronous and metachronous tumors. If the second tumor is detected 6 months after the diagnosis of the first tumor, it is called metachronous, and if detected within 6 months, it is called synchronous tumor.

It has been reported that the risk of developing a second tumor for each individual increases 1.1 times for each month after the diagnosis of the first primary tumor (2). Different factors such as genetic instability, gene mutation, immunodeficiency and persistent environmental carcinogens can also trigger the development of multiple tumors (3). In addition, prolongation of life span with chemotherapy, radiotherapy, chemoradiotherapy and target treatments are among the reasons that increase the development of the second primary tumor $(4,5)$.

In our study, we aimed to present the cases with MPTs that we detected among the cases discussed in the gastrointestinal system (GIS) council of our hospital, together with their clinicopathological features, in the light of literature information.

\section{Materials and Methods}

The cases with MPT criteria (1) among the cases diagnosed with primary tumor discussed for treatment and followup at the GIS councils held in our hospital between 2014 and 2019 were included in our study. Ethical approval for this study was obtained from Ethics Committee (06.30.2020/288).

In the council files, the primary tumor located in the GIS and tumors secondary to previously detected primary tumor were grouped as synchronous and metachronous tumors, respectively, according to their date of diagnosis. In addition to the demographic characteristics (age, gender of the cases and family history) obtained from the council files, from the pathology and hospital archives including the localization and histopathological diagnosis of MPTs, the diagnostic intervals of synchronous and metachronous tumors (in months according to their occurrence before or after the development of GIS tumor), and from the files of the cases, follow-up times (in months) were retrieved.

\section{Statistical Analysis}

Continuous variables were presented as median (interquartile range) or mean \pm standard deviation, according to their normality of distribution. Categorical variables were presented as numbers and percentages. The compliance of the numerical values to the normal distribution was examined using histograms or analytic methods (Kolmogorov-Smirnov/Shapiro-Wilk test). The Student's t-test was used to compare the means between the groups. The chi-square or Fisher's Exact test, where appropriate, was used to compare proportions between the groups. Survival data were evaluated using the KaplanMeier analysis and compared using the Log-rank test. An overall $p$-value less than 0.05 was considered as statistically significant. Statistical analyses were performed using the SPSS software v22 (IBM Inc, USA).

\section{Results}

\section{Clinical features of the cases}

Among the 3.546 cases discussed in the GIS council between 2014 and 2019, 162 cases (4.7\%) had a diagnosis of MPTs. While 65 (40.1\%) of the cases were female, 97 (59.9\%) were male. There were $52(32.1 \%)$ cases in the synchronous tumor group and $110(67.9 \%)$ cases in the metachronous tumor group. The mean age at diagnosis was $64.58 \pm 9.71$ years in the synchronous tumor group and $65.39 \pm 11.25$ years in the metachronous tumor group. Most of the cases in the synchronous and metachronous tumor groups were over 50 years old ( $92.3 \%$ vs $90.9 \%$ ). Both tumor groups were more common in males $(67.3 \%$ vs $56.4 \%)$. The mean time interval between the diagnoses of two primary tumors in the metachronous tumor group was 60 months (24-123 months). In this group, the first primary tumor detected in five patients was of GIS origin. In the other 105 cases, the GIS originated tumor was the second primary tumor. Time elapsed between the diagnoses of two primary tumors was 60 months (18-72 months) when GIS originated tumors were the first primary tumors, and 72 months (24-132 months) when the second primary tumor developed.

Cases with a family history of cancer were more numerous in the metachronous tumor group compared to the synchronous tumor group ( $9.6 \%$ vs $20 \%$ ), without a statistically significant intergroup difference $(\mathrm{p}=0.098)$. Left colon and stomach tumors were frequently observed among GIS tumors, while breast and prostate tumors were more common as the second primary tumors. 
Although the ratio of female to male patients was equal in 14 cases diagnosed with multiple tumors under the age of 50 years, female cases were more numerous in the metachronous tumor group than in the synchronous tumor group. The second primary tumors were mostly of lower GIS origin and more frequently observed in the metachronous tumor group. Relevant family history was found only in two cases in the metachronous tumor group.

The clinical features of all cases are presented in Table 1, and the clinical features of the cases in the group under 50 years of age are included in Table 2.

\section{Distribution of GIS tumors and their relationship with the second primary tumor group}

The most common locations of GIS tumors were the stomach $(28.4 \%)$, rectum $(25.9 \%)$, left colon $(21.6 \%)$ and right colon (12.9\%) in order of their frequencies. Locations in the esophagus (5.6\%), appendix (2.5\%), transverse colon (1.9\%) and anal canal (1.2\%) were observed less frequently. The most common tumor locations in males were the rectum (28.9\%) and stomach (26.8\%). In women, most frequently, tumors were seen in the stomach (30.8\%) and left colon (23.1\%). The most common MPT groups in males were left colon-prostate $(0.06 \%)$ and rectumright colon tumors $(0.06 \%)$, whereas in females they were stomach-breast $(0.2 \%)$ and left colon-breast tumors $(0.11 \%)$.
The second primary tumors accompanying GIS tumors in the synchronous and metachronous tumor groups belonged to the GIS (13\% vs $11.7 \%$ ) and the urogenital system ( $6.8 \%$ vs $16.7 \%)$. Colorectal tumor $(9.9 \%$ vs $9.3 \%)$ was most frequently detected in the GIS group, and prostate cancer $(3.1 \%$ vs $10.5 \%)$ was most often detected among urogenital system tumors. When tumor localizations were evaluated separately, it was found that GIS tumors were mostly accompanied by breast $(20.4 \%)$ and prostate (13.6\%) tumors. The most common accompanying gastric tumors among GIS tumors were breast (28.3\%) and prostate tumors (10.9\%).

The distribution of synchronous and metachronous GIS tumors according to their localizations is given in Table 3 , and the distribution of GIS tumors and second primary tumors according to their localizations is given in Table 4 .

\section{Histopathological findings of the cases}

The most common histological type of GIS malignancies was adenocarcinoma (83.3\%). Signet ring cell carcinoma (4.9\%), gastrointestinal stromal tumor (GIST) (3.1\%), squamous cell carcinoma (3.1\%), neuroendocrine tumor (2.5\%), mucinous carcinoma (2.5\%) and high-grade B-cell lymphoma $(0.6 \%)$ were other detected histological types. The majority of synchronous and metachronous tumors had morphologic features of adenocarcinoma $(73.8 \%$ vs. $88.2 \%)$.

\begin{tabular}{|c|c|c|c|c|}
\hline & $\begin{array}{l}\text { Synchronous } \\
(\mathrm{n}, \%)\end{array}$ & $\begin{array}{l}\text { Metachronous } \\
(n, \%)\end{array}$ & $\begin{array}{l}\text { Total } \\
(n, \%)\end{array}$ & $\mathbf{p}$ \\
\hline No. of patients & $52(32.1)$ & $110(67.9)$ & 162 & - \\
\hline Age. mean \pm SD & $64.58 \pm 9.71$ & $65.39 \pm 11.25$ & - & 0.654 \\
\hline \multirow[t]{4}{*}{ Median interval. mo } & - & $72(24-132)$ & - & - \\
\hline & & (for second tumor from GIS) & & \\
\hline & & $60(18-72)$ & - & - \\
\hline & & (for first tumor from GIS) & & \\
\hline Gender & & & & 0.185 \\
\hline Male & $35(67.3)$ & $62(56.4)$ & $97(59.9)$ & \\
\hline Female & $17(32.7)$ & $58(43.6)$ & $65(40.1)$ & \\
\hline Age at diagnosis of primary tumor & & & & 1 \\
\hline$<50$ & $4(7.7)$ & $10(9.1)$ & $14(8.6)$ & \\
\hline$\geq 50$ & $48(92.3)$ & $100(90.9)$ & $148(91.4)$ & \\
\hline Family history & & & & 0.098 \\
\hline Yes & $5(9.6)$ & $22(20)$ & $27(16.7)$ & \\
\hline No & $47(90.4)$ & $88(80)$ & $137(83.3)$ & \\
\hline First degree & $3(5.8)$ & $18(16.4)$ & $21(13)$ & \\
\hline Second degree & $2(3.8)$ & $4(3.6)$ & $6(3.7)$ & \\
\hline
\end{tabular}

MPT: Multiple primary tumor, mo: Month, GIS: Gastrointestinal system, SD: Standard deviation 
GIST, which is among the special diagnoses, was in four cases in the synchronous tumor group and in one case in the metachronous tumor group. It was located in the stomach in four cases and in the right colon in one case. Three of the accompanying secondary primary tumors were GIS tumors, and two of them originated from the breast and all of them had adenocarcinoma morphology. Neuroendocrine tumor detected in four cases was in the synchronous tumor group. All four cases were localized in the appendix. The second primary accompanying tumors were located in the GIS and one in the uterus (endometrium) which had adenocarcinoma morphology. High-grade B-cell lymphoma was also in the synchronous tumor group and was located in the right colon. The accompanying second primary tumor was located in the liver and was diagnosed as hepatocellular carcinoma.

The distribution of histopathological diagnoses of GIS tumors is given in Table 5 .

\section{Survival}

The mean follow-up period of all cases was 16 months (7.75-31 months) from the time of diagnosis. The median survival time of cases with synchronous tumors was 44 months [95\% confidence interval (CI), 33.8-54.2\%], and the median survival time of cases with metachronous tumors was 22 months (95\% CI, 18.8-25.2\%). While 1, 3 and 5-year survival rates were $79.4 \%, 58.3 \%$ and $42.7 \%$ in cases with synchronous tumors, they were $89.1 \%, 35.9 \%$ and $33.3 \%$ in cases with metachronous tumors, respectively. Although survival rates were found to be lower in cases with metachronous tumors than in cases with synchronous tumors, the intergroup difference was not statistically significant $(\mathrm{p}=0.086)$ (Figure 1A). During the follow-up period, $21(40.4 \%)$ of 52 cases in the synchronous tumor group and 55 (50\%) of 110 cases in the metachronous tumor group died.

The survival rate of cases with GIS malignancy originating from the stomach was lower compared to cases with other GIS malignancies, and this result was statistically significant ( $\mathrm{p}=0.002$ ) (Figure 1B).

The median survival time for cases in the group under 50 years old was 22 months (95\% CI, 8.4-35.7 months). The survival times of two patients with a relevant family history was significantly lower than those without an associated family history ( $\mathrm{p}=0.008)$ (Figure 2 ). Though not statistically

Table 2. Characteristics of the patients aging under fifty years

\begin{tabular}{llll} 
& $\begin{array}{l}\text { Synchronous } \\
(\mathbf{n}, \%)\end{array}$ & $\begin{array}{l}\text { Metachronous } \\
(\mathbf{n}, \%)\end{array}$ & $\begin{array}{l}\text { Total } \\
(\mathbf{n}, \%)\end{array}$ \\
\hline $\begin{array}{l}\text { No. of patients } \\
\text { Median interval. mo }\end{array}$ & $4(28.6)$ & $10(71.4)$ & 14 \\
Gender & - & $54(21-99)$ & - \\
Male & & & $7(50)$ \\
Female & $3(75)$ & $4(40)$ & $7(50)$ \\
Age at diagnosis of primary tumor & $1(25)$ & $6(60)$ & $5(35.7)$ \\
$\leq 45$ & & & $9(64.3)$ \\
$\geq 45$ & $2(50)$ & $3(30)$ & $2(14.3)$ \\
Family history & $2(50)$ & $7(70)$ & $12(85.7)$ \\
Yes & $0(0)$ & & $2(14.3)$ \\
No & $4(100)$ & $2(20)$ & $0(0)$ \\
First degree & - & $8(80)$ & 3 \\
Second degree & - & $0(80)$ & 11 \\
Second tumor & & & $16(7-29)$ \\
Upper GIS & $0(0)$ & 3 & $8(57)$ \\
Lower GIS & 4 & 7 & $6(43)$ \\
Follow-up, mo & $16(8.75-50.25)$ & $15.5(6.5-29)$ & \\
Final state & $3(75)$ & $5(50)$ & $5(50)$ \\
Alive & $1(25)$ & &
\end{tabular}

MPT: Multiple primary tumor, mo: Month, GIS: Gastrointestinal system 
significant, the survival times of the female cases were lower than those of male patients ( $\mathrm{p}=0.091$ ), and both cases with a relevant family history were women. In this group, there was no difference in survival rates between cases with synchronous and metachronous tumors ( $\mathrm{p}=0.492)$.

\section{Discussion}

The incidence of MPTs varies between $0.5 \%$ and $11.7 \%$ in the literature $(5,6)$. Among these tumors, the frequency of synchronous tumors is reported to be $30-55 \%(4,7)$. Our

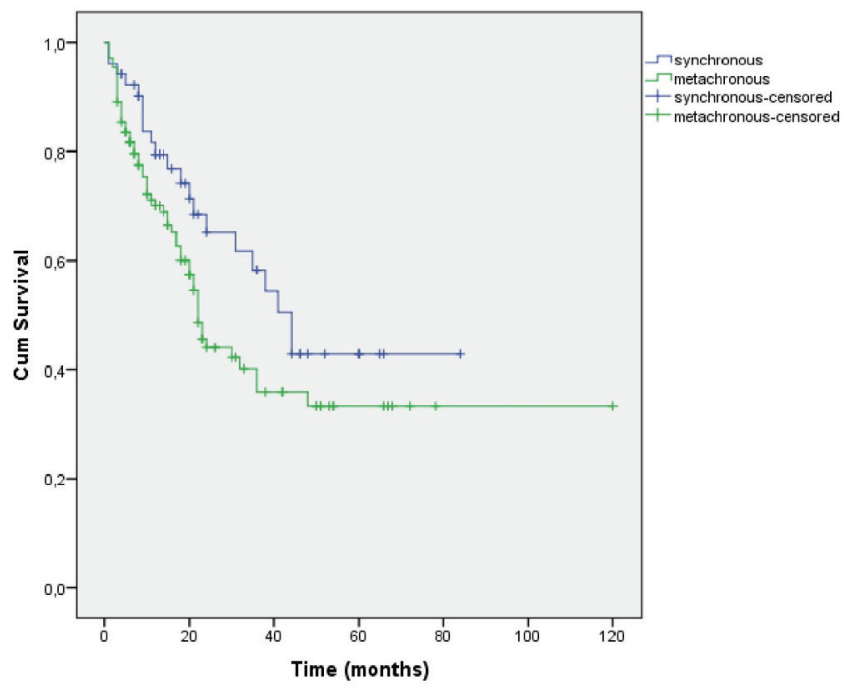

Figure 1A. Survival curve between synchronous and metachronous tumors

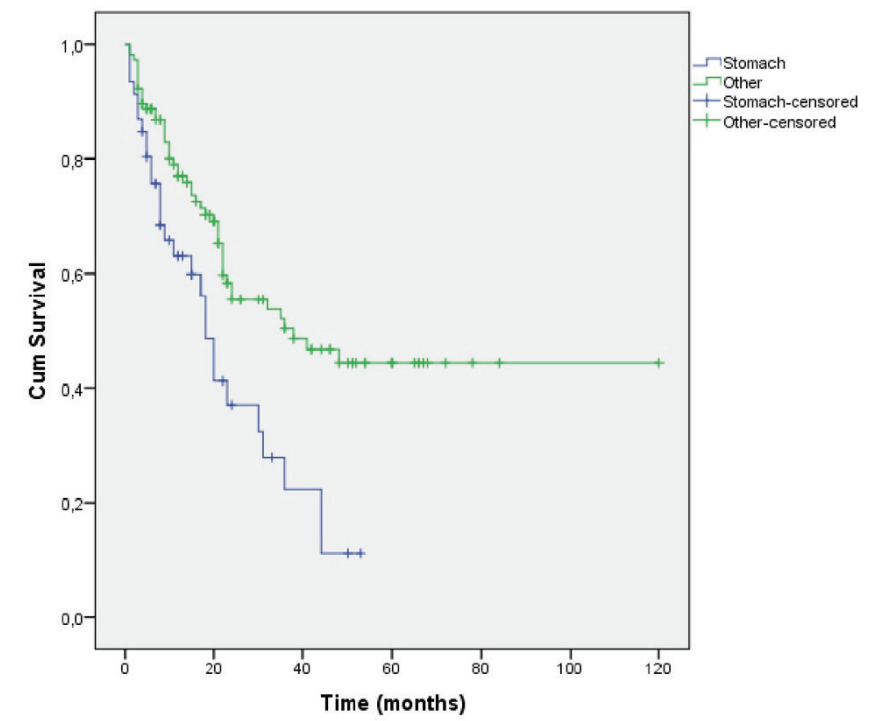

Figure 1B. Survival curve between stomach and other tumors rate of MPTs in our study was $4.7 \%$. Synchronous tumors were detected in $32.1 \%$ of the cases. These findings seem to be compatible with the literature. However, our study included only GIS tumors. This rate would have been lower if all system tumors had been included.

Although MPTs can be seen at any age, they are more common in patients at 50 years of age or older (8). In our study, most of the patients in the synchronous and metachronous tumor groups were over 50 years old $(>64.5$ years). Smaller number of cases were included in the group under 50 years of age, still more than half of these cases were observed in the metachronous tumor group. This finding was also compatible with the literature data (5).

MPTs are more common in men than in women. The male/ female ratio reported in the literature varies between 0.9 and 3.5/1 $(7,9,10)$. In our study, this rate was 1.5 which was consistent with the literature data. In our study, the mean time interval between the diagnoses of two primary tumors in the metachronous tumor group was 60 months. In the literature, this period varies between 60 months in cases with colorectal tumors and between 42 and 46.9 months in cases with gastric tumors $(4,11)$. This highlights the fact that the follow-up of cases with the diagnosis of primary tumor should be at least five years.

Among the reasons why synchronous tumors are observed more frequently in neighboring organs in MPTs, the concept of "field cancerization" can be mentioned. The upper respiratory tract, colorectal region, and lower

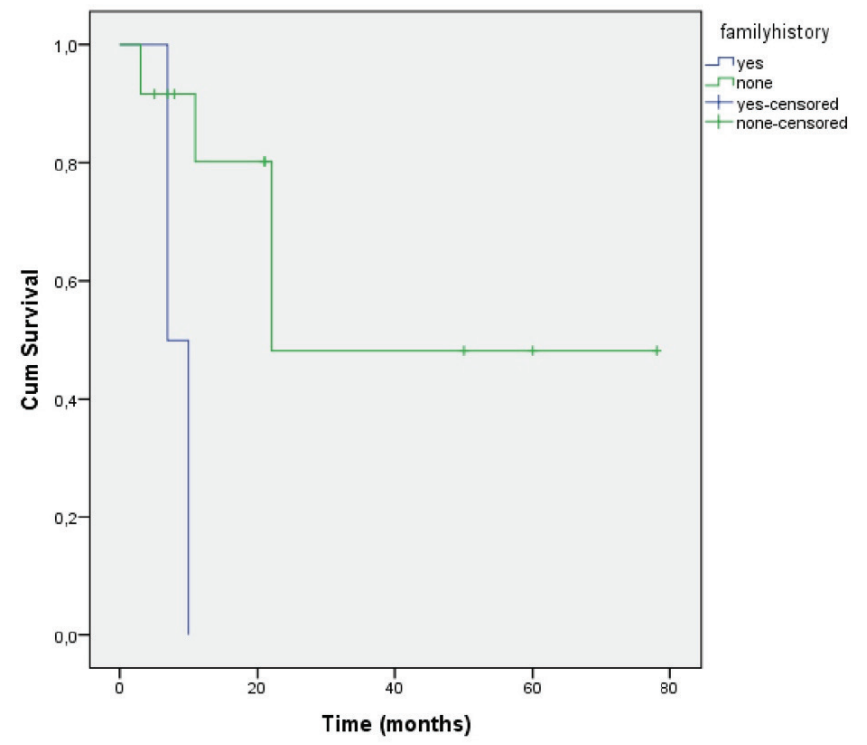

Figure 2. Survival curve of patients under 50 years of age with and without family history 
Table 3. The distribution of synchronous and metachronous tumors

\begin{tabular}{|c|c|c|c|c|c|}
\hline \multirow[b]{2}{*}{ Location } & \multicolumn{2}{|l|}{ Synchronous } & \multicolumn{3}{|c|}{ Metachronous } \\
\hline & Male (n, \%) & Female $(n, \%)$ & Male (n, \%) & Female (n, \%) & Total $(\mathbf{n}, \%)$ \\
\hline Esophagus & $1(0.6)$ & $1(0.6)$ & $5(3.1)$ & $2(1.2)$ & $9(5.6)$ \\
\hline Stomach & $9(5.6)$ & $6(3.7)$ & $17(10.5)$ & $14(8.6)$ & $46(28.4)$ \\
\hline Right colon & $5(3.1)$ & $3(1.9)$ & $7(4.3)$ & $6(3.7)$ & $21(12.9)$ \\
\hline Transverse colon & 0 & 0 & 0 & $3(1.9)$ & $3(1.9)$ \\
\hline Left colon & $6(3.7)$ & $4(2.5)$ & $14(8.6)$ & $11(6.8)$ & $35(21.6)$ \\
\hline Rectum & $11(6.8)$ & $2(1.2)$ & $17(10.5)$ & $12(7.4)$ & $42(25.9)$ \\
\hline Anal canal & 0 & 0 & $2(1.2)$ & 0 & $2(1.2)$ \\
\hline Appendix & $3(1.9)$ & $1(0.6)$ & 0 & 0 & $4(2.5)$ \\
\hline Total & $35(21.6)$ & $17(10.5)$ & $62(38.3)$ & $48(39.6)$ & $162(100)$ \\
\hline
\end{tabular}

\section{Table 4. The distribution of GIS tumors and second primary tumors according to their localizations}

\begin{tabular}{|c|c|c|c|c|c|c|c|c|c|c|c|}
\hline Location & Eso & Stom & $\mathrm{RC}$ & $\mathrm{TC}$ & LC & Rec & $A C$ & App & Sync Tm & Met Tm & Total $(n, \%)$ \\
\hline \multicolumn{12}{|l|}{ GIS (n) } \\
\hline Esophagus & - & - & - & - & - & 1 & - & - & 1 & - & $1(0.6)$ \\
\hline Small bowel & - & 1 & - & - & - & 1 & - & - & 2 & - & $2(1.2)$ \\
\hline Appendix & - & - & - & - & - & - & - & - & - & - & 0 \\
\hline Colorectal & 1 & 6 & 6 & 1 & 5 & 9 & - & 3 & 16 & 15 & $31(19.1)$ \\
\hline Breast (n) & 3 & 13 & 4 & 2 & 7 & 4 & - & - & 5 & 28 & $33(20.4)$ \\
\hline \multicolumn{12}{|l|}{ US (n) } \\
\hline Prostate & 2 & 5 & 3 & - & 6 & 5 & 1 & - & 5 & 17 & $22(13.6)$ \\
\hline Kidney & - & - & 1 & - & 2 & 1 & - & - & 3 & 1 & $4(2.5)$ \\
\hline Bladder & - & 3 & - & - & 1 & 4 & - & - & 3 & 5 & $8(4.9)$ \\
\hline Thyroid & - & 2 & - & - & 1 & 1 & - & - & - & 4 & $4(2.5)$ \\
\hline SG & - & 1 & - & - & - & - & - & - & 1 & - & $1(0.6)$ \\
\hline \multicolumn{12}{|l|}{ RS (n) } \\
\hline Lung & 1 & 1 & - & - & 4 & 4 & - & - & 5 & 5 & $10(6.2)$ \\
\hline Larynx & - & 2 & 1 & - & 1 & 1 & - & - & 1 & 4 & $5(3.1)$ \\
\hline \multicolumn{12}{|l|}{ FGS (n) } \\
\hline Cervix uteri & - & 1 & - & - & - & - & - & - & - & 1 & $1(0.6)$ \\
\hline Uterus & - & 1 & 1 & - & 1 & 4 & - & 1 & 2 & 6 & $8(4.9)$ \\
\hline Ovary & - & 1 & - & - & 3 & 2 & - & - & 2 & 4 & $6(3.7)$ \\
\hline Total (n) & 9 & 46 & 21 & 3 & 35 & 42 & 2 & 4 & 52 & 110 & $162(100)$ \\
\hline
\end{tabular}

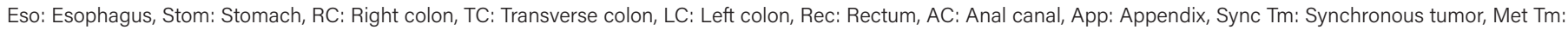

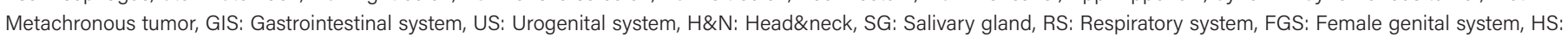
Hepatobiliary system, Hemato.S: Hematopoietic system 
Table 5. Histopathologic characteristics of MPTs

\begin{tabular}{llll}
$\begin{array}{l}\text { Histologic type of } \\
\text { GIS malignancy }\end{array}$ & $\begin{array}{l}\text { Synchronous } \\
(\mathbf{n}, \%)\end{array}$ & $\begin{array}{l}\text { Metachronous } \\
(\mathbf{n}, \%)\end{array}$ & $\begin{array}{l}\text { Total } \\
(\mathbf{n}, \%)\end{array}$ \\
\hline $\begin{array}{l}\text { Adenocarcinoma } \\
\begin{array}{l}\text { Signet ring cell } \\
\text { carcinoma }\end{array}\end{array}$ & $38(73.8)$ & $97(88.2)$ & $135(83.3)$ \\
$\begin{array}{l}\text { Gastrointestinal } \\
\text { stromal tumor }\end{array}$ & $4(5.8)$ & $5(4.5)$ & $8(4.9)$ \\
$\begin{array}{l}\text { Squamous cell } \\
\text { carcinoma }\end{array}$ & $1(1.9)$ & $1(0.9)$ & $5(3.1)$ \\
$\begin{array}{l}\text { Neuroendocrine } \\
\text { tumor }\end{array}$ & $4(7.7)$ & $4(3.6)$ & $5(3.1)$ \\
$\begin{array}{l}\text { Mucinous carcinoma } \\
\text { High grade B-cell }\end{array}$ & $1(1.9)$ & 0 & $4(2.5)$ \\
lymphoma & $1(1.9)$ & $3(2.7)$ & $4(2.5)$ \\
\hline
\end{tabular}

MPT: Multiple primary tumor, GIS: Gastrointestinal system

urinary tract are the locations where this effect is frequently observed (10). The presence of similar genetic changes can be counted among the reasons (5). In addition, advanced endoscopic and radiological examinations can enable simultaneous recognition of tumors in neighboring organs more easily (10). The results we obtained in our study also supported these possibilities. Indeed, the second primary tumors in the synchronous tumor group originated from the digestive and the urogenital system.

Family history of cancer is among the reasons that increase the probability of developing a second primary tumor. Positive family history has been reported, especially in cases with breast and ovarian tumors (12). In a study, it was observed that approximately half of the patients with MPTs had gastric tumors in their first and second-degree relatives (13). In our story family history of cancer was detected in 2 cases in the group of patients aged less than 50 years. While colon and gastric tumors were prominent among GIS tumors, breast and prostate tumors were found to be the second most common accompanying primary tumors.

In our study, the second primary tumors in the patients under 50 years of age were mostly originated from lower GIS. In cases with a relevant family history and under 50 years of age diagnosed with GIS malignancy, mismatch repair genes, APC and TP53 mutations are genetic tests recommended for those developing colorectal cancers $(13,14)$. As in our study, genetic analysis including these mutations may be included in screening methods for metachronous lower GIS tumors that may occur especially in young cases.
According to the SEER database in which cancer-related data are published, prostate-colorectal tumors in men and breast-colorectal tumors in women are the most common MPTs $(15,16)$. In our study, an association of left colonprostate and rectum-right colon tumors was observed in males, whereas an association of tumors in the stomachbreast and left colon-breast was observed in females. Especially, the more frequent detection of breast and colorectal tumors can be attributed to the use of improved screening methods (16).

In our study, gastric tumors ranking on top among GIS tumors were most frequently accompanied with breast and prostate tumors. In the literature, it has been observed that stomach tumors are more often accompanied by colorectal tumors $(17,18)$.

Hormonal treatment applied after the diagnosis of breast tumor may increase the risk of developing a second primary tumor also invading the stomach.

In addition, a strong relationship between hereditary gastric cancers and lobular breast tumors was mentioned (16). These data may explain the higher frequency of stomachbreast tumor association that we found in our study. Tumors of the rectum were the second most frequently seen tumors in our study, and they were accompanied by the right colon and prostate tumors. This result was compatible with the literature $(15,18)$.

In our study, the most common histological type found in GIS malignancies was adenocarcinoma. Special diagnoses included GIST, neuroendocrine tumor and high- grade B-cell lymphoma. GIST is the most frequently diagnosed mesenchymal tumor of GIS. It can be detected together with other GIS malignancies as a synchronous and a rare metachronous tumor $(19,20)$. It often accompanies stomach and esophageal carcinomas. It has been reported in the literature that cases with MPTs, including GIST, show a worse prognosis (5). In our study, it was localized in the stomach in four cases, and in two of these cases, it was synchronously associated with gastric carcinoma. Two cases with GİST localized in the stomach died during the follow-up.

In the literature, it has been reported that synchronous or metachronous second primary tumors can be observed in $35 \%$ of the cases with appendiceal tumors (21). In addition, approximately half of neuroendocrine tumors can be observed in association with second primary tumors in the appendix (22). In our study, all four cases of neuroendocrine tumor were located in the appendix. The most common 
organ with extranodal lymphoma involvement is GIS. However, association of lymphoma and GIS malignancy is extremely rare. A case with synchronous hepatocellular carcinoma with diffuse large B-cell lymphoma located in the lymph node has been reported in the literature (23). In our study, high-grade B-cell lymphoma with synchronously diagnosed hepatocellular carcinoma was located in the right colon.

MPTs have a worse prognosis than a single primary tumor. In particular, the synchronous tumor group shows a worse clinical picture in terms of survival $(5,24)$. In our study, unlike the literature, the survival time, though not statistically significant, was shorter in patients with metachronous tumors compared to patients with synchronous tumors. This may lead us to the conclusion that the follow-up times and examinations of our patients diagnosed with primary tumor are not sufficient. In addition, the survival rate of patients with gastric GIS malignancies in our study was lower compared to the patients with other GIS malignancies. In the literature, the 5-year survival rate for cases with primary gastric tumor is reported as less than $30 \%$ (25). The most important cause of poor prognosis in these tumors is diagnosis made at an advanced stage of the disease. It is important to detect gastric tumors at an early stage in order to increase survival rates. For this purpose, methods similar to screening methods used for breast and colorectal tumors can also be applied for gastric tumors.

\section{Conclusion}

In terms of GIS tumors, prostate and colon tumors in men and breast tumors in women may be risk factors for the development of MPTs. In cases with gastrointestinal tumors, the gastrointestinal and urogenital system, where detection of a second primary tumor is likely, can be monitored more closely. In addition, studies for genetic analysis of metachronous tumors that may develop in patients with primary tumors at a young age can be included in screening methods. In addition to these, since the life span of the patients has increased, in cases with primary tumors, it is important to complete all necessary tests and examinations, and to keep follow-up periods much longer.

\section{Ethics}

Ethics Committee Approval: Ethical approval for this study was obtained from Ethics Committee (06.30.2020/288).

Informed Consent: Consent was obtained.

Peer-review: Internally peer-reviewed.

\section{Authorship Contributions}

Concept: S.Ş.E., S.T.D., Design: S.Ş.E., S.T.D., A.A., Data Collection or Processing: S.Ş.E., S.T.D., A.A., E.U., Literature Search: S.Ş.E., S.T.D., E.U., Analysis or Interpretation: S.Ş.E., S.T.D., A.A., E.U., Writing: S.Ş.E., S.T.D., E.U.

Conflict of Interest: No conflict of interest was declared by the authors.

Financial Disclosure: The authors declared that this study has received no financial support.

\section{References}

1. Warren S, Gates O. Multiple primary malignant tumors: A survey of the literature and statistical study. Am J Cancer 1932;9(16):13581414.

2. Campbell LV, Watne AL. Multiple primary malignant neoplasms. Arch Surg 1969;99(3):401-405.

3. Mehdi I, Shah AH, Moona MS, Verma K, Abussa A, Elramih R, et al. Synchronous and metachronous malignant tumours expect the unexpected. J Pak Med Assoc 2010;60(11):905-909.

4. Liu z, Liu C, Guo W, Li S, Bai O. Clinical analysis of 152 cases of multipl primary malignant tumors in 15,398 patients with malignant tumors. Plos One 2015;10(5):e0125754. doi: 10.1371/ journal.pone.0125754.

5. Lv M, Zhang X, Shen Y, Wang F, Yang J, Wang B, et al. Clinical analysis and prognosis of synchronous and metachronous multiple primary malignant tumors. Medicine (Baltimore) 2017;96(17):e6799. doi: 10.1097/MD.0000000000006799.

6. Doğu GG, Yaren A, Taşköylü BY, İșler K, Değirmencioğlu S. Synchronous and metachronous double primary cancer patients: Single center experience. Pamukkale Medical Journal 2012;5(1):14 .

7. Aydıner A, Karadeniz A, Uygun K, Tas S, Tas F, Disci R, et al. Multiple primary neoplasms at a single institution: Differences between synchronous and metachronous neoplasms. Am J Clin Oncol 2000;23(4):364-370.

8. Demandante CGN, Troyer DA, Miles TP. Multiple primary malignant neoplasms case report and a comprehensive review of the literature. Am J Clin Oncol 2003;26(1):79-83.

9. Engin K. Cancers in multipl primary sites. Int Surg 1994;79(1):3337.

10. Ikubo A, Matsufuji S, Morifuji Y, Koga H, Kobarai T, Kouya N, et al. Clinical features, prognosis, diagnostic approaches and treatment of multipl primary malignancies in the digestive system. Anticancer Res 2019;39(12):6863-6870.

11. Shah BK, Khanal A, Hewett Y. Second primary malignancies in adults with gastric cancer-A US population-based study. Front Oncol 2016;6(82):1-4

12. Motuzyuk I, Sydorchuk O, Kovtun N, Palian Z, Kostiuchenko Y. Analysis of trends and factors in breast multiple primary malignant neoplasms. Breast Cancer 2018;12: 1178223418759959. doi: 10.1177/1178223418759959

13. Lawniczak M, Gawin A, Jaroszewicz-Heigelmann H, RogozaMateja W, Raszeja-Wyszormirska J, Bialek A, et al. Synchronous 
and metachronous neoplasms in gastric cancer patients: A 23-year study. W J Gastroenterol 2014;20(23):7480-7487.

14. Ballester V, Cruz-Correa M. How and when to consider genetic testing for colon cancer? Gastroenterol 2018;155(4):955-959.

15. Hayat MJ, Howlader N, Reichman ME, Edwards BK. Cancer statistics, trends, and multiple primary cancer analyses from the Surveillance, Epidemiology, and End Results (SEER) Program. The Oncologist 2007;12(1):20-37.

16. Vogt A, Schmid S, Heinimann K, Frick H, Herrmann C, Cerny $\mathrm{T}$, et al. Multiple primary tumors: challenges and approaches, a review. Esmo Open 2017;2(2):e000172. doi: 10.1136/ esmoopen-2017-000172.

17. Lam AK, Chan SS, Leung M. Synchronous colorectal cancer: Clinical, pathological and molecular implications. W J Gastroenterol 2014;20(22):6815-6820.

18. Kim JH, Rha SY, Kim C, Kim GM, Yoon SH, Kim KH, et al. Clinicopathological features of metachronous or synchronous gastric cancer patients with three or more primary sites. Cancer Res Treat 2010;42(4):217-224.

19. Wang YP, Song C. Metachronous multiple gastrointestinal stromal tumors and adenocarcinoma of the colon: A case report. Oncol Letters 2014;8(3):1123-1126.
20. Du J, Shen N, He HS, Fu XL, Wang JZ, Mao CZ. Synchronous gastrointestinal cancer and gastrointestinal stromal tumor: a single-institution experience. W J Surg Oncol 2016;14:130.

21. Iwuagwu OC. Jameel JKA, Drew PJ, Hartley JE, Monson JRT. Primary carcinoma of the appendix - Hull series. Dig Surg 2005;22(3):163167.

22. Habal N, Sims C, Bilchik AJ. Gastrointestinal carcinoid tumors and second primary malignancy. J Surg Oncol 2000;75(4):310-316.

23. Meng J, Pan H, Li X, Liu T, Liu Z, Li Q, et al. Diagnosis and treatment of synchronous lymphoma and digestive system carcinoma: Report of four cases and literatüre review. Front Oncol 2019;9:1367. doi: $10.3389 /$ fonc.2019.01367

24. Etiz D, Metcalfe E, Akcay M. Multiple primary malignant neoplasms: A 10-year experience at a single institution from Turkey. J Cancer Res Ther 2017;13(1):16-20.

25. Park JY, von Karsa L, Herrero R. Prevention strategies for gastric cancer: A global perspective. Clin Endosc 2014;47(6):478-489. 